\title{
Crime Prevention on Farms: The Opinion of Farmers ${ }^{1}$
}

Emmanuel K. Bunei

Associate Lecturer

Department of Social and Development Studies

Mount Kenya University

P.O. Box 69

Lodwar, Kenya

Joseph K. Rono

Lecturer, Department of Sociology and Psychology,

Moi University

P.O. Box 3900

Eldoret, Kenya.

Samuel R. Chessa

Lecturer, Department of Sociology and Psychology,

Moi University

P.O. Box 3900

Eldoret, Kenya.

Contact Author - E. K. Bunei; ebunei2001@yahoo.com, +254 724917456

\begin{abstract}
Crime rates in rural Kenya continue to increase, with a majority of farms experiencing more and more crime. These experiences have prompted rural farmers to opt for tactics that have the potential to minimize their own risk to victimisation, but which do not address the economic and social structural causes of crime in Kenya. This article reports on the findings of a study conducted on the adoption of farm crime prevention measures and their relationship to past victimisation experiences. Data for this study came from a survey of 200 farmers who were randomly selected in Uasin Gishu County of Kenya. The study was guided by routine activities theory, dividing crime prevention actions possibly adopted by farmers into two types: guardianship and target-hardening. The general finding is that the guardianship actions were utilized more often to reduce risk of victimisation than targethardening measures.
\end{abstract}

\section{Keywords: Crime Prevention; Farm Crime; Guardianship; Target Hardening; Crime Prevention}




\section{Introduction}

"The men I hired to guard the farm are not enough. I wish the crop (green maize) dries fast for harvest to discourage thieves." (A distraught farmer cited from The Standard Newspaper, 2013)

Since her independence in 1963, agriculture has been one of the strongest sectors of the Kenyan economy. However, like other sectors of the economy, the industry is crumbling with significant challenges, such as increased cost of production, unpredictable weather, low investment, and crime - all of which, among other challenges, are threatening to thwart its predominance as a leading contributor to Kenya's economic well-being (Republic of Kenya 2006; Daily Nation 2012; Star Newspaper 2012; The Standard Newspaper 2013a). Crime in particular has hit an alarming rate in the country, with rural areas experiencing an increasing rise of criminal activities.

Hardly a day goes by in Kenya without the media reporting crimes against farm operations and actions taken by farmers to prevent repeat occurrences of victimisation (Daily Nation 2012; Star Newspaper 2012; The Standard Newspaper,2013a). Most farm crimes reported by the media in Kenya include thefts of livestock, coffee, grain, fuel, green maize, tools, equipment, and the illegal planting of marijuana (The Standard Newspaper 2011, 2012; The Star 2013). Theft of donkeys is increasingly a major threat to small holder agriculturalists (Pearson, Nengomasha and Kreek 1999; Mutua 2004). Criminals steal donkeys during the night, slaughter them, and secretly sell their meat as beef from cows to unsuspecting citizens (The Standard Newspaper 2012). Sadly, most of these crimes are not correctly recorded by police, hence, official police statistics do not depict the true state of crime in Kenya, and particularly to farms.

Unlike urban areas in Kenya where a law enforcement presence is felt, rural areas suffer from limited police resources and response (Aronson, 2010; Republic of Kenya, 2006). In most cases, police visits are limited and if they do visit, it is a follow-up to an investigation or report of a violent crime or other illegal behaviours (Aronson, 2010). Rarely are they serious about investigating property crimes, especially those against farms, preferring to put more priority and resources to "urgent and important" offences such as murder, rape, escaping weigh bridges, or to tip-offs and follow-up investigations of illegal bhang production (a drink derived from the female cannabis plant) (Daily Nation 2012; The Standard Newspaper 2012).

These crime risk situations are compounded by the geographical and topographical characteristics of rural areas in Kenya (Republic of Kenya 2006). Many farmers in Kenya live far from their property, and most of the time they are unavailable to guard their property on a 24-hour basis. Farms in this nation are considerably large, remote (Republic of Kenya, 2006), and isolated. These agricultural operations have inventory (machinery, tools and supplies) that is valuable, accessible, and portable; which is frequently left unguarded during the night and the off-season. These farms provide perfect opportunities for criminals to steal and make off with their purloined goods with little chance of being caught. 
Theft of farm property in Kenya is becoming more professional, with criminal events that are well planned, choreographed and coordinated, hence, leaving little trace of evidence and making it more difficult to track them and make an arrest (The Standard 2013b). They target farm properties that fetch high prices and are quick to dispose of this property, such as pregnant cows, heifers, bulls, rams, cockerels, injector pumps, exotic breeds, coffee, and maize (Daily Nation 2012; The Standard Newspaper 2013a). They also operate during specific times and seasons of the year, such as the rainy season and at night when guardianship is more difficult. Cattle theft in Kenya is in fact a multimillion business that is well-organized, involving networks of police, unscrupulous owners of butcher shops, and drivers (often community members) who transport the stolen goods. All are out to make money by stealing from farmers (The Standard 2013b).

Farmers rarely use anything other than obvious security precautions, such as relocating cow sheds (The Standard Newspaper 2013b), padlocking fuel tanks, sleeping next to their property, ear notching their livestock, and locking up supplies, even though the walls of many storage sheds are made from materials which are easy to break through.

It is against this backdrop that we decided to assess the effectiveness of crime prevention interventions from the perspective of farmers themselves. We sought their opinions on which crime prevention tactics they would use to reduce their risk to crime and how this is related to prior victimisation. Our main concern was the doubt that most agricultural crime intervention measures are not effective, as evidenced by several media reports (The Standard Newspaper 2011; Daily Nation 2012; Star Newspaper 2012; The Standard Newspaper 2013a). It was puzzling to us that farmers were in agreement that farm crimes were increasing but still use the same strategies to combat crimes on their farms. This leads to the main question of this article: Do farmers believe crime prevention strategies at the individual (i.e., farmer) level work, as evidenced by the practices they adopt in relationship to their prior experiences with theft and vandalism?

Unfortunately, few rigorous assessments of crime prevention measures have been done anywhere in the world, and more specifically in Africa (Poyner 2009; Fraser 2011). Worse still, an assessment of agricultural crime prevention is limited if not non-existent (Fraser 2011), except in Australia (Anderson and McCall 2003; Barclay, Donnermeyer, Doyle and Talary 2001; Barclay and Donnermeyer 2011) and the U.S. (Mears. Scott and Bhati 2007a, 2007b). Rural crime, and in particular property crimes, such as theft, pose a difficulty to farmers who may not have sufficient resources and knowledge about prevention (Mears et al 2007a). Preventing theft of farm property is a serious problem to Kenyan farmers who have resorted to taking matters into their hands by enduring cold nights guarding their property, keeping harmful chemicals in their main house, or intentionally killing an alleged offender (The Standard Newspaper 2011; Daily Nation 2012; Star Newspaper 2012; The Standard Newspaper 2012). 


\section{A Review of Literature on Farm Crime Prevention Interventions}

Crime prevention measures can be adopted proactively before crime occurs, or as a reaction to the experience of crime. When instituted before or in anticipation of a crime, it is referred to as primary prevention and if taken after the crime has occurred, it is called secondary prevention. Secondary prevention represents security measures put into place following a victimisation is intended to avoid repeat occurrences (Anderson and McCall 2003).

Most crime reduction tactics in rural localities are aimed at minimising the opportunities for crime to occur by increasing the risk to someone who intends to commit the crime. Situational crime prevention theory is built around this same premise, that is, offenders calculate risk, which in turn, influences their decision to target (or not) either property or person for crime. Hence, the major aim of crime prevention is to make the costs of crime greater than the benefits by reducing accessibility, visibility, and attraction of crime targets, as well as improving guardianship through increased visibility (Felson 2002). Geason and Wilson (1988) argue that situational crime prevention strategies are intended to attenuate specific types of crime by modifying immediate environments in a systematic and permanent way.

Situational crime prevention strategies aim at preventing the intersection in time and space of offenders and targets in the absence of guardianship by making targets less attractive. As such, situational crime prevention techniques depend on the premises underlying routine activity theory (Cohen and Felson 1979). This model argues that crime occurs when there is a convergence of motivated offenders and attractive targets in the absence of capable guardians. Thus, crime can be prevented through reducing a potential thief's motivation by increasing perceived risk, improving guardianship techniques, and by making targets both less accessible and less attractive.

Barclay et al. (2001) found in Australia that farm security measures are more of a reaction to experiencing crime than a way of a proactively reducing victimisation. Farmers adjust by making a series of changes to their farming practices, such as increasing family labour rather than relying on non-family farm workers, locking stores, marking property with the hope of making theft difficult by discouraging re-sale and aiding the police in establishing property ownership when stolen items are recovered (Barclay et al 2001). In a similar study by Anderson and McCall (2005), also based on the experiences of farmers and crime in Australia, most victims were found to implement farm crime preventive interventions only after a crime occurred. Further, Barclay et al. (2001) found out that all but one farm crime prevention measure, namely, owning a dog, was ineffective in minimizing theft on farms.

Targets on a farm represent either the farmers themselves or their property which can be attacked, stolen, or damaged. Hence, to reduce farm theft, these targets need to be made more difficult to steal or damage by decreasing their attraction, visibility and exposure. This can be done, for example, by increasing the chance of recovering the property by inscribing a mark or registration on the item or disabling equipment when not in use (Eck 2002). 
Guardianship measures involve security techniques put in place to prevent or restrict access to the target (Mears et al 2007a). Guardianship has the goal of protecting targets and can take many forms. Most actions which increase guardianship are related to changes in farm management practices. They can include adjusting a person's normal or routine behaviour, which can increase surveillance and scare off or deter opportunistic offenders. A farmer or business owner also can increase guardianship when individuals are hired who are specifically employed to protect people and property such as security guards and private police. Farmers also can enhance guardianship with a dog, improved lighting near buildings, locking up their stores more frequently, fitting buildings with alarm systems, putting up no trespass signs, and returning tools and equipment to a storage facility when they are not being used so that they are out of sight of thieves and easier to be accounted for by the owner (Mears et al 2007b; McCall and Peter 2003; Barclay et al 2001). In a survey by McCall and Peter (2003) carried out in Australia, the occurrence of repeat victimisations was found to be related with the ineffectiveness of crime reduction strategies. They argued, quite simply, that if crime occurs repeatedly to the same victim who had instituted preventive measures, then the action did not work.

Another form of guardianship is the informal creation of an alliance between neighbours to keep an eye on one another's property. A more formal version of this straightforward principle is the start-up of a neighbourhood or community watch by the police or a local civic organisation, which entails encouraging interaction and a sense of responsibility between members of the community. It is generally recognised today that the active participation of society is essential to the effective prevention of crime. Community participation is an important part of any effort to reduce and prevent crime. Communities in which members maintain good relations amongst themselves and work together cooperatively to prevent crime can be the best deterrent, and improve personal safety and household security (Barclay et al 2001; Anderson and McCall 2005; Mears et al 2007b). Members of the community are encouraged to keep an eye on each other's properties and report suspicious incidents to the police (McCall and Homel 2003; Deeds et al 1992).

However, this approach to prevention is limited by focusing on the crime event itself (Bull 2007), which does not solve the deeper social structural, cultural, and economic issues which are the more fundamental causes of crime in a society. Hence, this approach does little to reduce the motivation of offenders, many of whom have no other alternative for acquiring monies to support themselves and their families. Crime prevention measures associated with increased guardianship and target-hardening, therefore, can be criticised as merely displacing crime by either making the criminal focus on easier targets or shifting to a type of crime that is easier to commit without getting caught. While crime might be reduced in one locality, the overall crime rate in a society may not drop, and could even increase (Cornish and Clarke 1986). According to Mears et al. (2007b), attempts to institute measures that reduce opportunities for crime to occur on a farm are not likely to succeed in decreasing agricultural crime over-all because the risks associated with farming today are due to fundamental changes in how food is produced, which is a shift toward larger and more mechanised production methods. It has also been found that situational crime prevention interventions 
may not be effective in circumstances where well-organised offenders have professional skills which can help them defeat security measures without detection (Bull, 2007).

\section{Method}

The focus of the study was farmers' assessment of actions which reduce and prevent crimes from occurring to agricultural operations. We started by reviewing numerous media reports about farm crime to establish background information for this study. A survey of farmers was carried out in 2012 on the effectiveness of farm crime prevention strategies. A multi-stage sampling technique was employed to randomly select 200 farming households in Uasin Gishu County of Kenya (see Figure 1).

Data was collected using a semi structured questionnaire and key informant interviews. The questionnaire asked farmers about agricultural crime victimisation during five years previous to the time of the interview. Also, farmers were asked if they themselves or family members had been victims of crimes on their farms or premises and whether or not in their opinion specific types of crime prevention measures were effective in reducing risk to victimisation. The focus specifically was on situational farm crime prevention measures, including both improvements in guardianship and target hardening tactics. Farmers also were asked to give information on the type of agricultural production and characteristics of their operations.

The study concentrated on seven major types of agricultural crime, including: livestock theft; theft of farm machinery, tools, and spare parts (including vehicle or machinery parts); theft of farm produce with special reference to grain; theft of agrichemicals (pesticides, herbicides and inputs); theft of farm tools and implements; fuel theft; and vandalism.

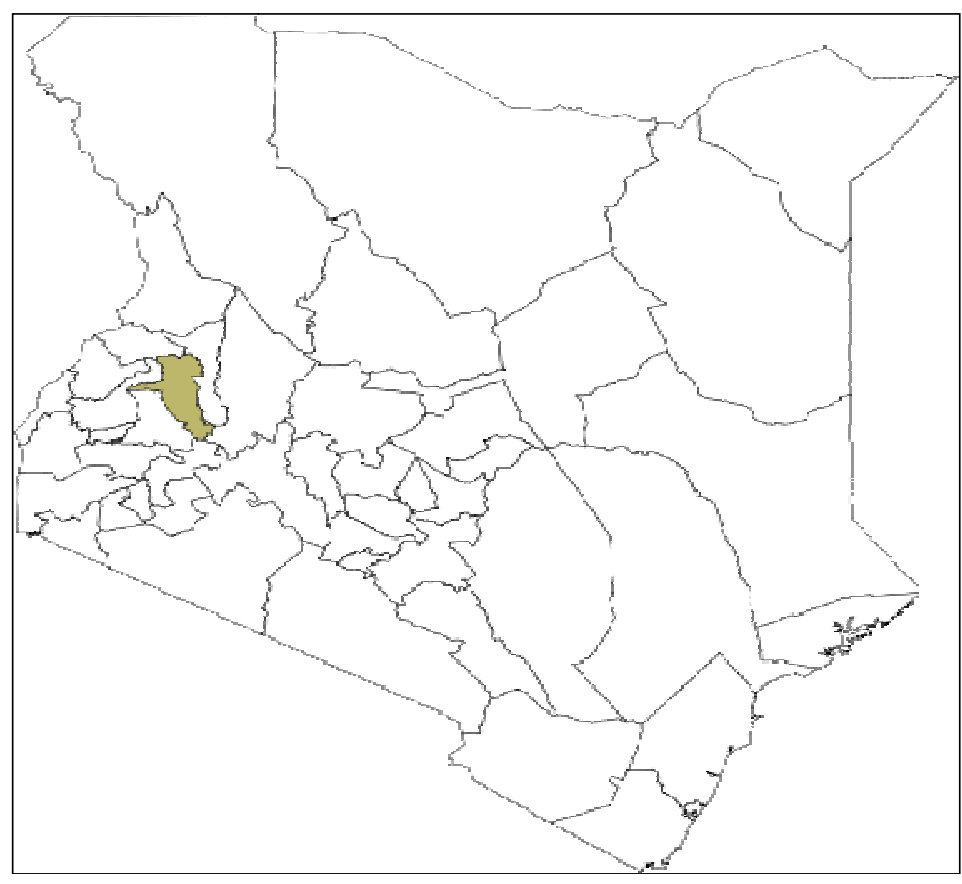

Figure 1: Area of Research Site in Kenya (Uasin Gishu County) 


\section{Measures}

In this article, the dependent variables were of two types: adoption of actions to improve guardianship and actions to improve target hardening. Each dependent variable was dummy coded $1=$ Yes, $0=$ No. Guardianship variables were measured by presence of a $\operatorname{dog}(\mathrm{s})$; increases in vigilance or monitoring of employees; strict supervision/accounting for the location of machinery; employing a guard; employing relatives/extended family members as farmworkers; vetting employees; rewarding honest employees; firing troublesome employees; and talking to employees about the cost of farm thefts and the consequences if caught. Target hardening variables included: locking up of fuel and agrichemicals; fencing areas on the farm; strengthening cow pens and poultry houses; branding of tools and grain bags; and housing machinery.

\section{Data analyses}

To facilitate analysis and exploration of meaningful relationships between the variables, the current study used logistic regression analysis due to the binary character of the dependent variables (Hosmer and Lemeshow 2000). The descriptive statistics utilized in this article include frequency distributions and percentages.

\section{Results and Discussion}

\section{Farm Crime Victimization}

Farmers were asked if they had been the victims of farm crimes in the last five years. This was intended to provide a background of farmers' experiences to the main theme of the study. The study revealed that the vast majority of farmers $(85 \%)$ have been victims of tool and small equipment theft, and 81 percent had experienced grain theft (Table 1). The least occurring crimes were fuel theft $(23 \%)$ and the theft of machinery $(15 \%)$. Finally, nearly half said they had been the victims of vandalism. Of the 200 farmers in this study, 99 percent (198) reported experiencing at least one crime incident during the past five years.

\section{Table 1 Farm Victimization Experiences}

Type of Theft $(n=200)$

\begin{tabular}{lc}
\hline Livestock & 45 \\
Fuel & 23 \\
Grain & 81 \\
Tools and small equipment & 85 \\
Agricultural chemicals & 48 \\
Machinery & 15 \\
Vandalism & 47 \\
Others (Green maize, timber fencing post \& beans) & 9 \\
\hline
\end{tabular}




\section{Guardianship Measures}

One way of limiting victimisation is to increase guardianship. The actions displayed in Table 2 include preventive measures which could make it more risky for an offender to enter the farm property and commit a crime without being observed. As Table 2 indicates, $86 \%$ of participants reared dogs, $56 \%$ believed that being vigilant and monitoring employees can deter farm theft, $32 \%$ personally supervised their machinery while being utilised away from home/central work area, $32 \%$ employed guards on their farms and farm premises, and 30\% hired their relatives as employees. All these actions are geared towards improving guardianship measures and serve to limit the chances of offenders committing thefts on the farm, since they are more likely to be noticed.

The majority of farmers use dogs to alert them when offenders intrude on their farms. They were of the opinion that dogs helped them greatly in making them aware of intruders at night. However, most of them were definite that a dog is not effective if the dog knows the offender. The offender could befriend the dog during the day in order to commit a theft at night. According to farmers, those suspects who were largely known to the dog included close neighbours, friends, employees and relatives who may be out at night without the dog barking. Generally, dogs are used by the farmers to guard their farm premises, not their residence.

There is a limited use of guards and of hiring of relatives as employees. In fact, some farmers reported that guards and other employees were more likely to be the offenders who steal and sell farm properties. Hired relatives in particular often take full advantage of the trust given to them by their employers. For many farmers, the bottom line on guardianship is that it is their own responsibility to keep a close watch on property and premises. As one respondent remarked:

"There are three critical periods in a year in which thefts by employees occur frequently: planting, harvesting and when applying agrichemicals. For you to prevent theft at this time, you need to be present yourself."

Table 2 Guardianship Measures Related to Detection of Intruders

\begin{tabular}{lcccccc}
\hline \multirow{2}{*}{ Guardianship Measures } & \multicolumn{2}{c}{ No } & \multicolumn{2}{c}{ Yes } & \multicolumn{2}{c}{ Total } \\
& $\mathbf{N}$ & $\boldsymbol{\%}$ & $\mathbf{N}$ & $\mathbf{\%}$ & $\mathbf{N}$ & $\%$ \\
\hline Rearing dog(s) & 27 & 14 & 169 & 86 & 196 & 100 \\
$\quad$ Vigilance and monitoring of & 87 & 44 & 110 & 56 & 197 & 100 \\
$\quad$ employees & 80 & 68 & 38 & 32 & 118 & 100 \\
$\begin{array}{l}\text { Supervising machinery } \\
\text { Employing a guard }\end{array}$ & 133 & 68 & 64 & 32 & 197 & 100 \\
$\begin{array}{l}\text { Hiring of employees who are } \\
\quad \text { relatives }\end{array}$ & 137 & 70 & 60 & 30 & 197 & 100 \\
\hline$\quad$
\end{tabular}


A second set of guardianship practices seeks to prevent crime by establishing a stronger working relationship with non-family farm workers. Employees have access to farm property and as a result they can occasionally be offenders. Over time, good employer-employee relationships can help in curbing thefts. Results from the study (Table 3) showed that, according to the respondents, developing and maintaining good relations with employees can be important for security. Of the 197 participants, $77 \%$ reported trying to hire honest employees, $74 \%$ talked to their employees about negative effects of farm thefts, $51 \%$ vetted their new employees, and $31 \%$ discontinued the service of employees as soon as they realized these workers were problematic.

Rewarding honest workers mitigates farm thefts since it can increased guardianship by loyal workers as they go about daily work routines. When employees are genuinely rewarded, they feel part of the family and the farm operation and reduce victimisation. Further, good relations with employees not only reduces loss of property but also improves care of property and closer monitoring of offenders.

One participant in the study had the following to say:

"In order for you to minimize theft by employees; you need to allow your shepherd to keep one animal (livestock). He/she will feel the same pain with yours when his/her stock is stolen."

It was also found that occasional discussions between farmer and employees on the effect of farm thefts can be a deterrent. Most of the farmers (74\%) were of the opinion that talking with farmers reduces farm theft. Close farmer and employee relationships helps guard farmer's property through fear of the consequences of farm theft, such as development of mistrust, loss of job, and so on. Firing an employee can have serious ramifications since sacked employees will have known the farm in terms of physical arrangements, the whereabouts of the owner, other family members and other farm employees, and various security measures, such as dogs. They also know weaknesses and points of entry to the farms and may give information to prospective offenders. It can be assumed that farmers can play a role in precipitating crime on their farms by improper handling or mismanagement of employees, which potentially cause them to be alienated.

Table 3 Improvement of Farm Management as a Crime Prevention Strategy

\begin{tabular}{lcccccc}
\hline & \multicolumn{2}{c}{ No } & \multicolumn{2}{c}{ Yes } & \multicolumn{2}{c}{ Total } \\
Crime prevention Strategies & N & \% & N & \% & N & \% \\
\hline Rewarding of honest employees & 46 & 23 & 151 & 77 & 197 & 100 \\
Discussing farm thefts with & 50 & 25 & 147 & 75 & 197 & 100 \\
$\quad$ employees & & & & & & \\
Vetting of new employees & 97 & 49 & 100 & 51 & 197 & 100 \\
Firing problem employees & 136 & 69 & 61 & 31 & 197 & 100 \\
\hline
\end{tabular}




\section{Target Hardening Strategies}

Target hardening involves the process of making items or properties less attractive, appealing and accessible for theft, vandalism and other crimes to potential thieves. For example, farmers could use put locks (or better locks) on their structures, fence in certain areas, relocate or reposition livestock paddocks, store machinery when not in use, and name or brand tools and equipment. One advantage of hardening targets is that it makes it difficult for offenders to access the property in a short time and it provides evidence of theft. Adoption of these techniques is shown in Table 4. Sixty-five percent of the respondents said they lock up their agrichemicals, 64 percent fence their land, 44 percent house their machinery, 43 percent have relocated their livestock house, 43 percent have labelled their tools and equipment, 27 percent put locks on fuel tanks, and 30 percent put marks on the grain sacks.

In this study, many farmers reported that they were storing their agrichemicals in their main house but this can be a serious health risk. Expensive chemicals such as Round-up and Primo gram were mostly stored in the bedroom of the farm owner. Some respondents have relocated their cow pens or poultry cages to a place within sight of their main house at night. Both of these strategies also increase guardianship because the property is closer to where the farmer is on a regular or daily basis.

Unlike other target hardening strategies, marking grain sacks was the least used strategy since many farmers believed that it was hard to differentiate one farmer's grain from another, once taken to market. Generally, branding of tools and equipment was rarely used by farmers. Small tools were hardly branded and farmers normally use the natural marks on animals. This makes it hard for police to adequately charge suspected offenders since farmers do not have substantial proof of their claim.

Table 4 Techniques of Target Hardening

\begin{tabular}{l|cc|cc|cc}
\hline \multirow{2}{*}{ Target Hardening Measures } & \multicolumn{2}{|c|}{ No } & \multicolumn{2}{c|}{ Yes } & \multicolumn{2}{c}{ Total } \\
\cline { 2 - 8 } & N & $\%$ & N & $\%$ & N & $\%$ \\
\hline Locking of agrichemicals & 69 & 35 & 127 & 65 & 196 & 100 \\
Ensuring proper fencing & 70 & 36 & 126 & 64 & 196 & 100 \\
Housing machinery at night & 66 & 56 & 53 & 44 & 119 & 100 \\
Relocating cow shed and poultry & 110 & 57 & 83 & 43 & 193 & 100 \\
$\quad$ cages & & & & & & \\
Branding of tools and equipment & 113 & 57 & 84 & 43 & 197 & 100 \\
Pad-locking of fuel tank & 87 & 73 & 33 & 27 & 120 & 100 \\
Marking of grain sacks & 138 & 70 & 59 & 30 & 197 & 100 \\
\hline
\end{tabular}




\section{Regression Analysis}

This study sought to examine the adoption of crime prevention measures used by farmers to control or minimize farm thefts based on prior victimisation experiences (Table 5). The analysis provides insights into the kinds of guardianship and target-hardening measures farmers believe would work to prevent the risk of future victimizations. The physical nature of farms in terms of remoteness, size, and isolation makes it harder for farmers to implement adequate security measures. In order to test the effectiveness of these measures, based on the opinions of farmers themselves, a regression model of various kinds of farm thefts as the dependent variables were conducted with 14 prevention measures, including: having pets (dogs), increase in vigilance, strict supervision of machinery, employment of a guard, employment of a relative, vetting employees, rewarding honest employees, firing troublesome employees, talking to employees about farm thefts, locking of fuel or agrichemicals, fencing farms, relocating cow pens or poultry cages, branding of tools or grain bags, and housing of machinery.

The results indicated that all but three measures of improving guardianship were significantly related to at least one type of farm theft experienced over the previous five years. The majority of farm thefts occur at night and in remote places where there are minimal guardianship measures. Even though these results are only the perceptions of respondents, they do suggest which types of prevention they adopted were more likely to make a difference.

The findings have revealed that there is an association between rearing dogs and prior experience with livestock theft $(b=0.059$, $p$-value $<0.05)$ and theft of grain $(b=0.071$, $p$ value $<0.05)$. Livestock and grain thefts do occur mostly at night when farmers are asleep. The fierce nature of dogs serves to limit potential offenders from stealing farmers' property, and alert farm owners of offenders on their premises. Thus, dogs can be source of help to farmers because most farm property thefts occur due to lack of capable guardianship in relation to both space and time.

Employing guards $(b=0.255, \mathrm{p}$-value $<0.05)$ and strict supervision $(b=0.945, \mathrm{p}$-value $<0.05)$ were significantly associated with being the victim of agrichemical theft. Farmers may opt to employ guards for their property, especially when farm properties are far away from where the farmer lives. This can be attributed to the size of farms and scattered landholdings, and number of employees who would know where chemicals are stored in the absence of capable guardians. Further, agrichemicals can be readily sold to other farmers or unscrupulous dealers.

Rewarding honest employees $(b=0.227$, $\mathrm{p}$-value $<0.05)$ and vetting new employees $(b$ $=0.668$ p-value $<0.05$ ) had a statistical significant relationship with prior theft of tools and small equipment, according to respondents in this study. Proper rewards in terms of payment of wages on time and better treatment of employees may be two effective ways to guard against farm theft. It was interesting to note that attempts to increase guardianship measures by employing a relative and firing a troublesome employee to act as a deterrent to others were 
not were related to prior victimisation experiences. This showed that farms are not immune from thefts by people known to farmers, especially relatives. Further, dismissing employees could exacerbate farm thefts, with some ex-employees giving out information to prospective offenders as a form of retaliation for being let go.

Analysis of the relationship between crime prevention techniques employed by farms and prior victimisation experiences found only one target hardening measures but one (relocating cow pen/poultry cage: $\mathrm{b}=0.590$, $\mathrm{p}$-value $<0.05$ ) to have a statistically significant relationship. This may be due to farmers failing to implement preventive measures in the first place, or the techniques themselves are believed to be ineffective. Items such as tools and equipment can be stolen and disposed off in far places limiting farmers' recovery of stolen items. Marked grain bags can be dismantled and grain taken rendering the sacks useless.

Altogether, the findings in Table 5 indicate that crime prevention measures, especially target-hardening, were not associated with prior experiences with crime, suggesting that farmers did not believe they would be effective in reducing future victimisations.

\section{Table 5 Logistic Regression Analysis of Different Types of Agricultural Crime on Guardianship and Target Hardening Measures}

\begin{tabular}{|c|c|c|c|c|c|c|c|}
\hline $\begin{array}{l}\text { Dependent Variable } \\
\text { Independent } \\
\text { Variables }\end{array}$ & $\begin{array}{c}\text { Livestock } \\
\text { Coefficients }\end{array}$ & $\begin{array}{c}\text { Fuel } \\
\text { Coefficients }\end{array}$ & $\begin{array}{c}\text { Grain } \\
\text { Coefficients }\end{array}$ & $\begin{array}{l}\text { Tool \& Small } \\
\text { Equipment } \\
\text { Coefficients }\end{array}$ & $\begin{array}{c}\text { Agrichemicals } \\
\text { Coefficients }\end{array}$ & $\begin{array}{l}\text { Machinery } \\
\text { Coefficients }\end{array}$ & $\begin{array}{c}\text { Vandalism } \\
\text { Coefficients }\end{array}$ \\
\hline Constant & -2.679 & -5.029 & -2.336 & -2.541 & -3.493 & -6.604 & -3.433 \\
\hline \multicolumn{8}{|c|}{ Improvement in Guardianship Measures } \\
\hline $\begin{array}{l}\text { Use of dogs } \\
\text { Vigilance and } \\
\text { monitoring of } \\
\text { employees }\end{array}$ & $\begin{array}{c}0.059^{* *} \\
0.415\end{array}$ & $\begin{array}{l}-0.531 \\
-7.43\end{array}$ & $\begin{array}{c}0.071 * * \\
0.092\end{array}$ & $\begin{array}{l}-0.335 \\
0.505\end{array}$ & $\begin{array}{l}-0.568 \\
-0.287\end{array}$ & $\begin{array}{l}-0.714 \\
-0.172\end{array}$ & $\begin{array}{c}1.319 * * \\
0.066\end{array}$ \\
\hline $\begin{array}{l}\text { Supervision of } \\
\text { machinery }\end{array}$ & - & 1.192 & - & -0.949 & $0.945^{* *}$ & $0.445^{*}$ & 0.130 \\
\hline Employ guards & 0.568 & $0.255^{*}$ & 0.884 & 0.237 & 0.047 & 0.627 & 0.391 \\
\hline Employee relatives & -0.222 & -0.455 & -0.061 & -0.093 & -0.312 & -0.444 & -0.048 \\
\hline Vetting Employees & 0.09 & 0.601 & 0.711 & $0.668 * *$ & 0.079 & -0.447 & 0.323 \\
\hline $\begin{array}{l}\text { Rewarding } \\
\text { employees }\end{array}$ & -0.061 & 0.25 & 0.229 & $0.227 * *$ & -0.255 & 0.095 & 0.144 \\
\hline Firing employees & 0.097 & 0.218 & 0.216 & -0.415 & -0.044 & $0.010^{* *}$ & -0.327 \\
\hline Talking to employees & -0.606 & 0.881 & 0.156 & -0.302 & 1.107 & 1.23 & -0.002 \\
\hline \multicolumn{8}{|l|}{ Target Hardening } \\
\hline Locking & - & 0.368 & - & - & 0.803 & - & - \\
\hline Fencing & -0.138 & - & 0.58 & 0.815 & 0.435 & 0.511 & -0.014 \\
\hline $\begin{array}{l}\text { Reconstructing cow } \\
\text { pens }\end{array}$ & $0.590 * *$ & - & - & - & - & - & - \\
\hline Branding of property & - & - & -0.119 & 0.307 & - & - & - \\
\hline Housing machinery & - & 0.12 & - & -0.139 & - & 0.49 & - \\
\hline R-Square & 0.445 & 0.096 & .091 & 0.242 & 0.042 & 0.080 & 0.094 \\
\hline
\end{tabular}

Note: $N=197 . * * p<.05, * p<.001$ 


\section{Summary and Conclusion}

The aim of this study was to examine the types of crime prevention actions adopted by farmers. From the study, it is clear that only certain prevention measures were seen as effective in minimizing and/or preventing thefts in the farms. The findings revealed that farmers generally sought improvements in guardianship measures to reduce the risk to farm theft more so than target hardening strategies.

Surprisingly, all target hardening measures, except one (relocating cow sheds and poultry cages) were not correlated with previous victimisation experiences. This mirrors the findings of research by Barclay et al (2001) in Australia and by Mears et al (2007b) in central California that target-hardening was not enthusiastically seen as a way to reduce risk. Relocation of cow sheds or poultry cages was found to be a popular action to adopt because the process of moving these structures increases the guardianship measures as well as preventing a motivated offender from accessing the target (cattle and poultry) when guardianship is more difficult.

Many of the situational farm crime prevention measures that are thought to lead to reductions in thefts on the farm are short-lived and may displace thefts from one property to another, one person to another, or change the nature of criminal activity and therefore will be neither effective in reducing crime over-all in an area nor to farms generally in Kenya. A mere change in the physical environment and design measures may not lead to sustained reductions in crime.

Efforts to improve security measures should entail three approaches envisaged by routine activity theory, namely, restricting motivated offender by increasing guardianship measures and target hardening property by making less attractive, accessible, visible and removable. However, target-hardening would not be effective if sources of motivations to commit crime are not reduced, and guardianship, although perceived to be more effective, does not solve the more fundamental problems for why people attempt to steal farm property. That would require countrywide improvements in employment opportunities and other changes to the economic and social structure of Kenyan society.

In conclusion, for sustained farm crime reduction, there is need to improve the social, cultural, political and economic environment of farm communities and of Kenyan society in general through interventions such as poverty reduction, youth empowerment, affordable middle level education, easy access to micro-credit finance, community policing, provision of youth recreational facilities and so on. In the meantime, farmers should adopt crime prevention measures, both guardianship and target-hardening actions, that they believe will work. 


\section{Endnotes}

${ }^{1}$ The authors wish to acknowledge with great appreciation, the support given to them by farmers in Uasin Gishu County who provided the necessary information during the survey and in particular, the village elders who assisted in the selecting and identifying of participants for this study. The findings, conclusions and any errors are however, entirely the authors' responsibility. 


\section{REFERENCES}

Anderson, K.M. and McCall, M. (2005). Farm crime in Australia. Canberra, AU: Australian Institute of Criminology, www.aic.gov.au/publications/current\%20series/cfi/101120/cfi119.aspx

Aronson S.I. (2010). Crime and development in Kenya: Emerging trends and the transnational implications of political, economic, and social instability. Students Pulses Journal, 2(9): 1-2. Available online from: http://www.studentpulse.com/articles/278/

Barclay, E., Donnermeyer, J. F., Doyle, B. P., \& Talary, D. ( 2001). Property crime victimisation and crime prevention on farms. Report to the NSW Attorney General's Crime Prevention Division (Report No. 01.2). Armidale, New South Wales: Institute for Rural Futures, University of New England.

Barclay, E., Donnermeyer J.F. (2011). Crime and security on agricultural operations. Security Journal, 24, 1-18.

Bull M. (2007). Crime prevention and rural communities. In Barclay, E., Donnermeyer, J.F., Scott, J. and Hogg, R.M. (Eds.), Crime in rural Australia (pp. 78-97). Sydney: Federation Press.

Cohen, L. E., \& Felson, M. (1979). Social change and crime rates trends: A routine activities approach. American Sociological Review, 44: 588-608

Daily Nation (2012). Three goats thieves suffer villagers wrath. Nation Media: Nairobi: 8. Publish on $29^{\text {th }}$ June, 2012.

Deeds, J., Frese, W., Hitchner, M., \& Solomon, M. (1992). Farm crime in Mississippi. Report to the Mississippi Agricultural and Forestry Experiment Station. Mississippi State, MI: Mississippi State University. Bulletin 987.

Eck , J. E . (2002). Preventing crime at places. In: L.W. Sherman, D.P. Farrington, B. Welsh and D.L. MacKenzie (Eds.) Evidence-based crime prevention (pp. 241-294). New York: Routledge.

Felson, M. (2002). Crime and everyday life," ( $3^{\text {rd }}$ edition). London: Sage.

Fraser, J. (2011). Rural crime prevention: A literature review. Department of Criminology, University of Ottawa; as retrieved on $13^{\text {th }}$ July, 2013 from: http://www.crimepreventionottawa.ca/uploads/files/publications/lit_review_rural_crime_prevention.pdf 
Geason, S., \& Wilson, P.R. (1988). Crime prevention: Theory and practice. Canberra: Australian Institute of Criminology.

Hosmer, D., \& Lemeshow, S. (2000). Applied logistic regression. New York, NY: Wiley.

McCall, M. and Peter H. (2003). Preventing crime on Australian farms: Issues, Current Initiatives and Future Directions. Australian Institute of Criminology, Trends and Issues in Crime and Criminal justice, No.268.

Mears, D.P., Scott, M.L., \& Bhati, A.S. (2007a). A process and outcome evaluation of an agricultural crime initiative. Criminal Justice Policy Review, 18, 51-80.

Mears, D.P., Scott, M.L., \& Bhati, A.S. (2007b). Opportunity theory and agricultural crime victimization. Rural Sociology, 72, 151-184.

Mutua, J. (2004). Some challenges to the use of donkeys in Kenya. In Starkey, P. and Kaumbutho P. (Eds), Donkeys, people and development (pp. 99-101). Wageningwen, Netherlands: ACP - EU Technical Centre for Agricultural and Rural Cooperation (CTA).

Peason,R.A., Nengomasha, E., \& Kreek R. (1999). The challenges in using donkeys for work in Africa. In Starkey, P. and Kaumbutho P. (Eds), Meeting the challenges of animal traction (pp. 190-198). London: Intermediate Technology Publications.

Poyner, B. (2009). What works in crime prevention: An overview of evaluations. Rutgers University. Retrieved on $13^{\text {th }}$ July, 2013 from http://www.popcenter.org/library/crimeprevention/volume_01/01poyner.pdf

Republic of Kenya (2006). Agrarian reforms and rural development: Challenges and options for revitalizing rural communities in Kenya: A national report of Kenya. Paper presented at the International Conference on Agrarian Reforms and Rural Development, Porto Alerge, Brazil. March, 2006.

Standard Newspaper (2012). Task force set to investigate donkey theft in Kenya. Standard Group, Nairobi: 3, Published on 21st September, 2012.

Standard Newspaper (2013a). Agony of farmer losing millions of shillings to bloody livestock merchants. Standard Group, Nairobi: 3, Published on $2^{\text {nd }}$ July, 2013.

Standard Newspaper (2013b). Why residents sleep a step away from their cattle. Standard Group, Nairobi: 27, Published on 10 ${ }^{\text {th }}$ August, 2013.

Star Newspaper (2012). Man stoned to death for stealing arrow roots. Star Media, Nairobi: 12. Published on $9^{\text {th }}$ June, 2012. 